Reprod. Nutr. Dévelop., 1981, 21 (5A), 727-735.

\title{
Comparative effects of some carbohydrates on serum sugars, triglycerides and digestive hydrolases
}

\author{
par Sophie NOIROT, Malika OUAGUED, Anik GIRARD-GLOBA \\ Centre de Recherches sur la Nutrition, CNRS \\ 9, rue Jules-Hetzel, 92190 Meudon Bellevue, France.
}

Summary. For 3 weeks, rats were fed diets containing 60 p. 100 carbohydrate in the form of starch (wheat flour), purified sucrose, commercial sugar or a commercial sweetner containing a mixture of glucose and fructose. Glycemia was lower during the day than at night, and it was lowest in the starch-fed group. Fructosemia, high in all groups during the day, suggested endogenous production ; it was low at night, showing efficient clearance of exogenous fructose. Triglyceridemia was highest in the rats fed purified sucrose and exhibited no light/dark variation in that group. It was higher in all the other groups during the day.

Regarding pancreatic hydrolases, starch, rather than sugars, raised pancreatic amylase, while lipase did not correlate with endogenous hyperglyceridemia and was similar in all groups. Commercial preparations significantly lowered chymotrypsinogen contents.

These results confirm that sucrose and equimolar mixtures of glucose and fructose are not equivalent (disaccharide effect). The data evidence an endogenous fructose production during the day and suggest that commercial sugar, often used in the preparation of diets, may have different effects than purified sucrose.

\section{Introduction.}

The nutritional impact of the dietary carbohydrate source has been widely studied. It is particularly well established that dietary saccharose or fructose stimulates hepatic lipogenesis (Bruckdorffer et al., 1972 ; Cohen et al., 1972 ; Romsos and Leveille, 1974 ; Tuovinen and Bender, 1975 ; Michaelis and Szepesi, 1974). Other effects however have been the object of divergent reports. For instance, some authors do not believe that all dietary carbohydrates stimulate pancreatic amylase to the same extent. Howard and Yudkin (1963) and Bucko ef al. (1969) found that fructose and saccharose were less efficient in that respect than glucose and starch, while Deschodt-Lanckman et al. (1971) reported that starch, glucose and saccharose had the same effect, and that only fructose was less stimulatory. It has also been reported that equimolar mixtures of glucose and fructose give different results than those obtained with sucrose (Howard and Yudkin, 1963 ; Thompson ef al., 1979 ; Michaelis ef al., 1975). Aside from the work of Bruckdorffer et al., most authors studying metabolic effects reported only one measurement per day and did not take into account the shift in metabolism from nocturnal glycogenogenesis to diurnal glycogenolysis and lipogenesis. Assuming that fructose 
could be handled differently by the organism, depending on whether it is present as a monosaccharide or a disaccharide, we compared diurnal and nocturnal levels of glycemia, fructosemia and triglyceridemia in rats fed diets containing sucrose, a mixture of glucose and fructose, or starch. Since circulating metabolites seem to be partly responsible for adapting pancreatic secretion to the diet (Ben Abdeljlil and Desnuelle, 1964 ; Lavau et al., 1974), we also compared levels of pancreatic hydrolases and intestinal sucrase-isomaltase.

Michaelis and Szepesi (1974) suggested that some of the discrepancies in the results might be due to the quality of the dietary carbohydrate. Commercial sugar is often used in semi-purified diets, while fructose and glucose are purified sugars. For this reason, we also compared sucrose to commercial sugar.

\section{Material and methods.}

Sixty-four Wistar male rats, weighing $100 \mathrm{~g}$, were divided into 4 groups, each receiving one of the diets (table 1) containing a different type of carbohydrate (starch,

TABLE 1

Composition of experimental diets (p. 100 of diet weight)

\begin{tabular}{|c|c|c|c|c|}
\hline \multirow[b]{2}{*}{ 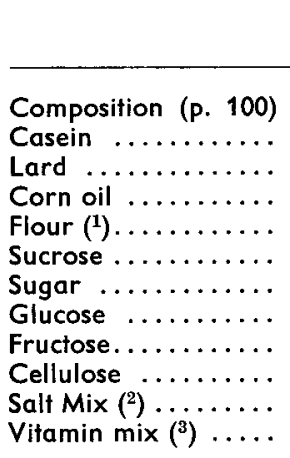 } & \multicolumn{4}{|c|}{ Diet } \\
\hline & $\begin{array}{c}\text { Starch } \\
11.4 \\
1.0 \\
0.6 \\
81.0 \\
- \\
- \\
- \\
- \\
1.3 \\
3.6 \\
2.0\end{array}$ & $\begin{array}{c}\text { Sugar } \\
21.5 \\
1.0 \\
0.6 \\
9.0 \\
\overline{-} \\
-1.3 \\
- \\
1.3 \\
3.6 \\
2.0\end{array}$ & $\begin{array}{c}\text { Sucrose } \\
21.5 \\
1.0 \\
0.6 \\
9.0 \\
61.3 \\
- \\
- \\
- \\
1.3 \\
3.6 \\
2.0\end{array}$ & $\begin{array}{c}\text { Sweetener } \\
21.5 \\
1.0 \\
0.6 \\
9.0 \\
- \\
- \\
31.0 \\
25.0 \\
1.3 \\
3.6 \\
2.0\end{array}$ \\
\hline $\begin{array}{l}\text { Protein............. } \\
\text { Carbohydrate . . . . }\end{array}$ & $\begin{array}{l}17 \\
61.9\end{array}$ & $\begin{array}{l}18.3 \\
68.7\end{array}$ & $\begin{array}{l}18.3 \\
68.7\end{array}$ & $\begin{array}{l}18.3 \\
68.7\end{array}$ \\
\hline
\end{tabular}

(1) Wheat flour containing 76.5 p. 100 carbohydrate and 14.0 p. 100 protein.

$\left({ }^{2}\right)$ Wesson type salt mix (NBC, Cleveland, Ohio).

(3) Vitamin fortification mixture (NBC, Cleveland, Ohio).

commercial sugar, purified sucrose or a commercial sweetner containing 50 p. 100 glucose, 42 p. 100 fructose, 8 p. 100 maltose and traces of polydextrins). These diets were fed for 21 days during which the animals were weighed at regular intervals and their food intake recorded.

At the end of the experimental period, the rats were killed by aortic exsanguination under light ether anesthesia. Half in each group were killed between 14.00 and $16.00 \mathrm{hrs}$. (light period) and the other half between 02.00 and $04.00 \mathrm{hrs}$. (dark period). The serum was collected and the pancreas and liver excised and frozen until assay; 
the intestine was also kept frozen after its contents had been washed away with an icecold solution of 0.9 p. $100 \mathrm{NaCl}$.

Serum glucose was determined by glucose-oxidase (Trinder, 1969) and serum fructose by the zirconium chloride procedure of Schlegelova and Hruska (1977). The value measured was corrected for a small glucose interference in the assay by subtracting from the apparent fructose measurement the value obtained with an amount of glucose equivalent to sample glycemia.

Serum cholesterol was determined according to Abell et al. (1952) and triglycerides by the enzymatic method of Wahlefeld (1974).

The pancreatic tissue was homogenized in 10 volumes of ice water. Amylase activity was determined as described by Dahlquist (1962) ; chymotrypsinogen was activated with trypsin and its activity measured on the synthetic acetyl-tyrosine-ethyl-ether substrate of Hummel (1959), measuring the release of acetic acid by continuous titrimetry on a Metrohm pH stat with $0.02 \mathrm{~N}$ sodium hydroxide. Lipase activity was estimated by a method based on the one described by Marchis Mouren, Sarda and Desnuelle (1959) at $\mathrm{pH} 9.0$ using a triolein substrate stabilized with gum arabic (triolein $45 \mathrm{ml}$, 10 p. 100 gum arabic $360 \mathrm{ml}$ ). The homogenate sample was added to $7 \mathrm{ml}$ of substrate with $1 \mathrm{ml}$ of buffer $\left(\mathrm{NaCl} 375 \mathrm{mM}, \mathrm{CaCl}_{2} 75 \mathrm{mM}\right)$ and $1 \mathrm{ml}$ of $10 \mathrm{p} .100 \mathrm{Na}$ tauroglycocholate. Under such conditions. lipase alone is inactive and requires colipase. A crude preparation of colipase was added to ensure full expression of lipase activity. The colipase contents of the sample were determined by an identical procedure, except that to destroy endogenous lipase activity the reaction mixture was brought to $\mathrm{pH} 2$ with $1 \mathrm{~N}$ $\mathrm{HCl}$ after addition of the sample. After the $\mathrm{pH}$ was restored to 9.0, a purified preparation of lipase was added and the colipase was estimated from the amount of lipase activity expressed.

Intestinal saccharase was measured by the method of Dahlquist (1968) on samples of 1 p. 100 tissue homogenates.

\section{Results.}

Food ingestion and weight gain. - After an initial adjustment period, all the groups fed identically. The rats receiving starch or commercial sugar gained significantly more $(P<0.01)$ than those fed purified sugar or commercial sweetner, but the differences did not exceed 10 p. 100 (fig. 1).

Plasma glucose and fructose. - In all the groups, glycemia was significantly higher during the digestive period at night than during the day (table 2). The highest levels were reached with the commercial sugar diet. The starch-fed rats had the lowest blood glucose, and the difference was most marked during the day when glycemia decreased in this group more than in those fed any of the sugars $(P<0.01)$.

Fructosemia (table 2), high during the day (36 to $58 \mathrm{mg}$ per $100 \mathrm{ml}$ ), was not any lower in the rats fed starch than in those receiving the sugars containing fructose. It was low at night, not exceeding $10 \mathrm{mg}$ per $100 \mathrm{ml}$, except in the rats fed commercial sugars and showing a significantly higher fructosemia than all the other groups $(P<0.01)$.

Plasma triglycerides. - Triglyceridemia (table 2) was lower at night, but owing to individual variation, the difference was significant only in the rats fed the glucose- 


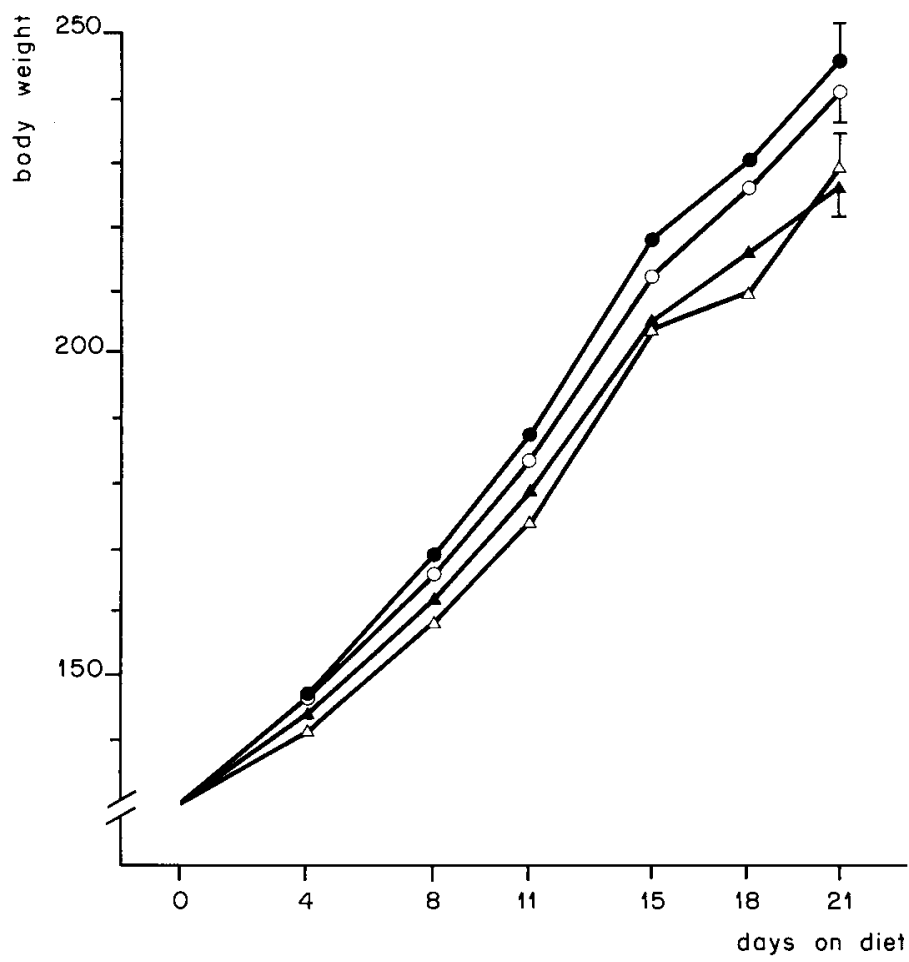

FIG. 1. - Body weight profile of rats during the experimental period.

Starch-fed : closed circles ; sugar-fed : open circles ; purified sucrose-fed : closed triangles ; glucosefructose sweetner-fed : open triangles. Each point is the mean of 8 animals. Vertical bars show the SEM.

TABLE 2

Plasma levels of glucose, fructose, and triglycerides (mg per $100 \mathrm{ml}$ )

\begin{tabular}{|c|c|c|c|c|}
\hline Diet & Period & Glucose & Fructose & Triglycerides \\
\hline $\begin{array}{l}\text { Starch } \ldots \ldots \ldots \\
\text { Sugar } \ldots \ldots \ldots \\
\text { Sucrose } \ldots \ldots \ldots \\
\text { Sweetener } \ldots \ldots\end{array}$ & $\begin{array}{l}\text { Day } \\
\text { Night } \\
\text { Day } \\
\text { Night } \\
\text { Day } \\
\text { Night } \\
\text { Day } \\
\text { Night }\end{array}$ & $\begin{array}{l}138 \pm 5.6 \\
186 \pm 6.0 y \\
166 \pm 7.9 a \\
208 \pm 4.6 x a \\
173 \pm 10.9 a \\
193 \pm 5.2 y \\
163 \pm 7.7 a \\
190 \pm 8.9 y\end{array}$ & $\begin{array}{c}46 \pm 8.9 \\
9 \pm 3.7 y \\
58 \pm 11.8 \\
34 \pm 8.3{ }^{a} \\
36 \pm 8.0 \\
10 \pm 6.0 x \\
37 \pm 4.9 \\
9 \pm 4.2 x\end{array}$ & $\begin{array}{l}177 \pm 20.3 \\
128 \pm 11.8 \\
229 \pm 30.3 \\
169 \pm 23.4 \\
246 \pm 17.9^{b} \\
250 \pm 19.3 a \\
241 \pm 25.7 b \\
146 \pm 22.3^{b}\end{array}$ \\
\hline
\end{tabular}

Values for each period are the means \pm SEM of 8 rats.

Significantly different from the " Day " group on the same diet: $x: \mathrm{P}<0.01 ; y: \mathrm{P}<0.05$.

Significantly different from control (starch) value for same period : ${ }^{a}: \mathrm{P}<0.01 ;{ }^{b}: \mathrm{P}<0.05$. 
fructose mixture $(P<0.01)$. The animals fed purified sucrose exhibited no diurnal variations and had uniformly high triglyceridemia. As expected, all the groups fed sugar had higher lipid levels than the starch controls, particularly during the day when triglyceridemia was most elevated.

Pancreatic hydrolases. - Amylase activity of the pancreatic tissue was significantly lowered by sugar feeding as compared to starch feeding (table 3). Chymotrypsinogen

TABLE 3

Pancreatic hydrolases (units per $g$ of tissue)

\begin{tabular}{|c|c|c|c|c|}
\hline Diet & Amylase & Chymotrypsin & Lipase & Colipase \\
\hline $\begin{array}{l}\text { Starch } \ldots \ldots \ldots \ldots \ldots \\
\text { Sugar } \ldots \ldots \ldots \ldots \ldots \ldots \\
\text { Sucrose } \ldots \ldots \ldots \ldots \\
\text { Sweetener } \ldots \ldots \ldots \ldots\end{array}$ & $\begin{array}{l}6.00 \pm 0.33 \\
4.64 \pm 0.18 a \\
4.51 \pm 0.45 a \\
4.50 \pm 0.45 a\end{array}$ & $\begin{array}{l}2.90 \pm 0.18 \\
2.16 \pm 0.18 a \\
2.73 \pm 0.30 \\
2.11 \pm 0.27 a\end{array}$ & $\begin{array}{rl}9.41 & \pm 0.46 \\
10.52 \pm 0.40 & b \\
10.57 \pm 0.65 \\
9.97 \pm 0.77\end{array}$ & $\begin{array}{l}8.26 \pm 0.46 \\
8.41 \pm 0.46 \\
9.36 \pm 0.72 \\
9.46 \pm 1.05\end{array}$ \\
\hline
\end{tabular}

The values are the means \pm SEM of 16 rats in each group.

Significantly different from starch controls: ${ }^{a}: \mathrm{P}<0.01 ;{ }^{b}: \mathrm{P}<0.05$.

was significantly decreased $(P \leqslant 0.01)$ by commercial preparations of both sugar and glucose-sucrose sweetener.

Lipase activity was slightly higher in the sugar-fed rats but reached only a moderately significant level $(P<0.05)$. Colipase was not significantly different in any of the groups.

Intestinal sucrase. - Sucrase activity was significantly higher at night in all groups (table 4), but was highest in the starch and sweetener-fed animals. It was significantly

TABLE 4

Intestinal Sucrose (units per total gut)

\begin{tabular}{cll}
\hline \multicolumn{1}{c}{ Diet } & Period & \multicolumn{1}{c}{ Sucrase } \\
\hline Starch $\ldots \ldots \ldots \ldots \ldots \ldots$ & Day & $17.2 \pm 1.47$ \\
Sugar $\ldots \ldots \ldots \ldots \ldots \ldots$ & $\begin{array}{l}\text { Night } \\
\text { Day }\end{array}$ & $32.0 \pm 1.96 x$ \\
Sucrose $\ldots \ldots \ldots \ldots \ldots \ldots$ & $\begin{array}{l}\text { Night } \\
\text { Day }\end{array}$ & $26.0 \pm 1.41$ \\
Sweetener............. & $14.9 \pm 1.09$ \\
& Night & $19.9 \pm 2.16 x a$ \\
& Day & $19.7 \pm 1.28$ \\
& Night & $29.3 \pm 2.43 x$ \\
\hline
\end{tabular}

Symbols as in table 2 .

lower in the other two groups, but particularly in that fed the purified sugar whose values differed from those of the other groups (starch, $P<0.01$; sweetener, $P<0.01$; commercial sugar, $P<0.05$ ). 


\section{Discussion.}

Feeding apparently equivalent sugar diets resulted in metabolic effects which were not identical in all respects at either the level of circulating metabolites or that of digestive enzymes.

Circulating glucose levels were high in all groups, even in those fed starch, because the animals were not fasted prior to killing. Glycemia was higher at night $(02.00$ to $4.00 \mathrm{hrs}$.) than during the day $(14.00$ to $16.00 \mathrm{hrs}$.). This result is in agreement with the findings of Peret et al. (1973), although Jolin and Montes (1973) reported a maximum around $18.00 \mathrm{hrs}$. and Gagliardino and Hernandez (1971) found maximal glycemia in mice between 8.00 and $12.00 \mathrm{hrs}$. The variation between day and night was more marked with the starch diet, the day/night ratio being 0.74 vs $0.80,0.89$ and 0.86 with the three sugar diets. The smaller amplitude of variation in sugar-fed rats was essentially due to the higher daytime levels when the animals were eating very little. Such poor blood glucose clearance during the period of relative fasting might indicate a diabetic tendency, as was evidenced by Bruckdorffer, Khan and Yudkin (1972), or to a perturbation in the light/dark pattern of insulinemia (Kalopyssis et al., 1979), consecutive to prolonged sugar feeding.

Fructosemia was about $10 \mathrm{mg}$ per $100 \mathrm{ml}$ during the night, which is within the range of values found by Bruckdorffer ef al. (1974). However, the daytime values were unexpectedly high. The zirconium chloride assay method was checked and shown to give results closely agreeing with the resorcinol technique of Roe (1934) employed by Bruckdorffer ef al. (1974). The only substance which could react in the same manner is sorbitol but it is highly unlikely that significant amounts would be found in the serum. Since fructosemia was significantly elevated, even in the starch-fed rats, it is probable that the fructose was of endogenous origin and should be investigated further. Bruckdorffer et al. (1974) also found a rise in fructosemia during the day, but it was of much lower amplitude. The same authors also reported a reversed pattern in sucrose-fed animals which did not occur in our experiment. However, sugar-fed rats did exhibit very high nocturnal fructose values as compared to the other groups. Compared to daytime values, the relatively low nocturnal levels of fructosemia are surprising in animals fed sucrose, sugar or glucose-fructose. The digestive processes by which fructose is absorbed are only partially clarified at present. According to Rérat ef al. (1978) studying swine, fructose appears in the portal vein, during sucrose digestion, in less than equimolar amounts as compared to glucose. This can be taken to mean that either fructose is absorbed more alowly than glucose, or rather that it is rapidly converted to glucose or to fatty acids by the enterocyte before it can appear in the circulation. In the present experiment where only peripheral concentrations were measured, the liver may have contributed further to fructose clearance. In this respect, it is interesting to compare the fructosemia and triglyceridemia levels in the rats fed commercial or purified sucrose. In the former, fructosemia remained very high at night, while triglyceridemia was moderate. In the latter, on the contrary, fructosemia was as low as in the other groups at night but triglyceridemia was considerably elevated. This emphasizes that a balance occurred between the two metabolites, and indicates that some contami- 
nant in commercial sucrose may partially impair the ability of the liver to convert fructose to fatty acids. In rats fed the glucose-fructose mixture, nocturnal clearance of fructose was very efficient but triglyceride output was low. Thompson et al. (1979) also reported a « disaccharide effect 》 in humans by which a mixture of glucose and fructose raises plasma triglycerides significantly less than an equivalent amount of sucrose. One possibility in that case is that, in the presence of glucose, the monosaccharide form of fructose is more efficiently converted to glucose than the disaccharide form and is therefore less lipogenic. In favour of this hypothesis is the fact that pancreatic amylase, which responds to glucose, was particularly high at night. On the whole, fructose was more efficiently cleared from the plasma than glucose. It is unlikely that this was due to poorer absorption since the animals on sugar gained as much weight as those on starch with a similar caloric intake. More likely, the fructose disappeared quicker because it was more readily taken up by the liver (Sillero ef al., 1969).

The investigation of a few key digestive hydrolases has yielded some interesting results. It is usually accepted that pancreatic amylase responds to glucose as well as to starch itself (Ben Abdeljlil and Desnuelle, 1964). Deschodt-Lanckman et al. (1971) found that saccharose stimulated amylase to the same extent as starch, while Howard and Yudkin (1963) reported lower levels. Our results agree with the latter and confirm the hypothesis that it is the glucose moiety of saccharose which acts on amylase production. But, in our study, blood glucose was, if anything, higher in the sucrose and sugar groups than in the starch group. It is therefore likely that if glucose is responsible for amylase induction, it must act at the intestinal level by a receptor mechanism such as that postulated in the rat by Dick and Felber (1975) and in swine by Simoes Nunes and Corring (1979). As we have seen above, rats fed the glucose-fructose mixture had a higher amylase level at night which might be due to more efficient conversion of fructose to glucose than in the disaccharide form. An incidental finding was that both commercial preparations significantly decreased pancreatic chymotrypsinogen contents, although protein intake was not diminished. It would be interesting to find out whether some minor contaminant due to industrial treatment might not be responsible for this effect since there is no significant nutritional difference between the sucrose and sugar diets.

Bucko, Simko and Kopec (1969) have reported an increase in lipase activity consecutive to sucrose feeding which they attributed to hyperlipemia. Our results do not support these findings as we observed no change in either lipase or colipase activity, despite a marked hyperlipemia.

The intestinal enzymatic complex of saccharase-isomaltase shows a clear-cut diurnal rhythmicity (Saito et al., 1976) which we have evidenced in all the groups. In our experiment, only sucrase activity was measured, but it is known to be induced by starch in parallel with isomaltase (Kolinska and Kraml, 1972). In the rats fed starch, it is not astonishing therefore to find high levels of sucrase which we interpreted as digestive adaptation to isomaltase. When the rats were fed purified sucrose, however, both the daytime base level and the nighttime stimulated level were decreased. Saccharase activity was slightly higher in rats fed commercial sugar, and in sweetener-fed rats it reached the values found with starch. This may mean that sucrose per se is not as good an inducer of the enzyme complex as starch, and that the small amounts of maltose or 
polydextrins contained in commercial sugar or sweetener may contribute to further stimulate sucrase-isomaltase.

Reçu en janvier 1981.

Accepté en avril 1981.

Résumé. Des rats ont reçu pendant 3 semaines des régimes contenant 60 p. 100 de glucides sous la forme soit d'amidon (farine de blé), de saccharose purifié, de sucre du commerce, ou d'un édulcorant contenant un mélange de glucose ef de fructose. La glycémie est plus basse pendant la période diurne que la nuit, surtout dans le groupe à l'amidon. La fructosémie est élevée en période diurne dans tous les groupes ce qui suggère une origine endogène. Elle est basse la nuit témoignant d'une bonne métabolisation du fructose exogène. Les rats nourris au saccharose ont une triglycéridémie élevée mais sans variation nycthémérale. Dans les autres groupes la triglycéridémie est plus élevée en période diurne.

Au niveau des hydrolases pancréatiques, l'amidon augmente l'amylase plus que les sucres, tandis que la lipase n'est pas corrélée avec l'hypertriglycéridémie endogène. Les préparations commerciales (sucre et édulcorant) abaissent significativement le chymotrypsinogène.

Ces résultats confirment la non-équivalence entre le saccharose et les mélanges équimolaires de glucose et de fructose (effet disaccharide). Ils mettent en évidence une production endogène de fructose pendant la journée et suggèrent que le sucre commercial, souvent employé dans la préparation de rations semi-synthétiques, pourrait avoir des effets un peu différents de ceux du saccharose purifié.

\section{References}

ABELL L. L., LEVY B. B., BRODIE B. B., KENDALL F. E., 1952. A simplified method for the estimation of total cholesterol in serum. J. biol. Chem., 195, 357-366.

BEN ABDELJLIL A., DESNUELLE P., 1964. Sur l'adapłation des enzymes exocrines du pancréas à la composition du régime. Biochim. biophys. Acta, 81, 136-149.

BRUCKDORFFER K. R., KHAN I. H., YUDKIN J., 1972. Fatty acid synthetase activity in the liver and adipose tissue of rats fed with various carbohydrates. Biochem. J., 129, 439-446.

BRUCKDORFFER K. R., KANG S. S., KHAN I. H., BOURNE A. R., YUDKIN J., 1974. Diurnal changes in the concentrations of plasma lipids, sugars, insulin and corticosterone in rats fed diets containing various carbohydrates. Horm. Metab. Res., 6, 99-106.

BUCKO A., SIMKO V., KOPEC Z., 1969. The effect of various kinds of carbohydrate on amylase formation in the pancreas. Nutr. Dief., 11, 203-213.

COHEN A. M., BRILLER S., SHAFRIR E., 1972. Effect of long-term sucrose feeding on the activity of some enzymes regulating glycolysis, lipogenesis and gluconeogenesis in rat liver and adipose tissue. Biochim. biophys. Acta, 279, 129-138.

DAHLQUIST A., 1962. A method for the determination of amylase in intestinal contents. Scand. J. clin. Lab. Invest., 14, 145-150.

DAHLQUIST A., 1968. Assay of intestinal disaccharidases. Analyt. Biochem., 22, 99-107.

DESCHODT-LANCKMANM., ROBBERECHT P., CAMUS J., CHRISTOPHE J., 1971. Short-term adaptation of pancreatic hydrolases to nutritional and physiological stimuli in adult rats, Biochimie, 53, 789.

DICK J., FELBER J. P., 1975. Specific hormonal regulation by food of the pancreas enzymatic (amylase and trypsin) secretion. Horm. Metab. Res., 7, 161-166.

GAGLIARDINO J. J., HERNANDEZ R. E., 1971. Circadian variation of serum glucose and immunoreactive insulin levels. Endocrinology, 88, 1529-1531.

HOWARD F., YUDKIN J., 1963. Effect of dietary change upon the amylase and trypsin activities of the rat pancreas. Brit. J. Nutr., 17, 281-294.

HUMMEL B. C. W., 1959. A modified spectrophotometric determination of chymotrypsin, trypsin and thrombin. Can. J. Biochem. Physiol., 37, 1393-1399.

JOLIN T., MONTES A., 1973. Daily rhythm of glucose and insulin levels in rats. Horm. Res., 4, 153-156. 
KALOPYSSIS A. D., GIRARD A., GRIGLIO S., 1979. Diurnal variations of plasma lipoproteins and liver lipids in rats fed starch, sucrose or fat. Horm. Metab. Res., 11, 118-122.

KOLINSKA J., KRAML J., 1972. Separation and characterization of sucrase-isomaltase and of glucoamylase of rat intestine. Biochim. biophys. Acfa, 284, 235-247.

LAVAU M., BAZIN R., HERZOG J., 1974. Comparative effects of oral and parenteral feeding on pancreatic enzymes in the rat. J. Nutr., 104, 1432-1437.

MARCHIS MOUREN G., SARDA L., DESNUELLE P., 1959. Purification of hog pancreatic lipase. Arch. Biochem. Biophys., 83, 309-319.

MICHAELIS O. E., SZEPESI B., 1974. The mechanism of a specific metabolic effect of sucrose in the rat. J. Nutr., 104, 1597-1609.

MICHAELIS O. E., NACE C. S., SZEPESI B., 1975. Demonstration of a specific metabolic effect of dietary disaccharides in the rat. J. Nutr., 105, 1186-1191.

PERET J., MACAIRE I., CHANEZ M., 1973. Schedule of protein ingestion, nitrogen and energy utilization and circodian rhythm of hepatic glycogen, plasma corticosterone and insulin in rats. $J$. Nutr., 103, 866-874.

RERAT A., VAUGELADE P., VAISSADE P., 1978. Kinetics of absorption of some carbohydrates in the pig. Xlth inf. Congr. Nutr., Abstr. No 91.

ROE J. H., 1934. A colorimetric method for the determination of fructose in blood and urine. J. biol. Chem., 107, 15-23.

ROMSOS D. R., LEVEILLE G. A., 1974. Effect of dietary fructose on in vitro and in vivo fatty acid synthesis in the rat. Biochim. biophys. Acta, 360, 1-11.

SAITO M., MURAKAMI E., SUDA M., 1976. Circadian rhythms in disaccharidases of rat small intestine and its relation to food intake. Biochim. biophys. Acta, 421, 177-179.

SCHLEGELOVA J., HRUSKA K., 1977. Determination of fructose by the zirconyl-chloride reaction. Analyt. Biochem., 79, 583-585.

SILLERO M. A. G., SILLERO A., SOLS A., 1969. Enzymes involved in fructose metabolism in liver and the glyceraldehyde metabolic crossroads. Europ. J. Biochem., 10, 345-350.

SIMOES NUNES C., CORRING T., 1979. Pancreatic exocrine secretion in the pig following test meals of different composition and intraduodenal loads of glucose and maltose. Horm. Metab. Res., 11, 346-351.

THOMPSON R. G., HAYFORD J. T., HENDRIX J. A., 1979. Triglyceride concentrations : the disaccharide effect. Science, 206, 838-839.

TRINDER P., 1969. Determination of glucose in blood using glucose oxidase, on alternative oxygen acceptor. Ann. clin. Biochem., 6, 24-27.

TUOVINEN C. G. R., BENDER A. E., 1975. Effect of dietary sucrose and fructose on the metabolism and lipid fractions in liver in the rat. Nutr. Mefob., 19, 1-9.

WAHLEFELD A. W., 1974. In Methoden der enzymatischen Analyse. 3rd Ed. Vol. Il p. 1878, H. U. BERGMEYER Veriag Chemie, Weinheim. 